\title{
SCAFFOLD FROM MICRO ELECTROSPUN POLYLACTIDE ACID AND WET CHEMICAL HYDROTHERMAL REACTION HYDROXY APATITE USED FOR BIOMEDICAL APPLICATION
}

\author{
NGUYEN THAI HOA ${ }^{1,2}$, PHAM TRUNG KIEN ${ }^{1}$, HUYNH DAI PHU ${ }^{1,3}$ \\ ${ }^{1}$ Faculty of Materials Technology, Bach Khoa University, \\ ${ }^{2}$ Material Technologies Laboratory, Bach Khoa University, \\ ${ }^{3}$ National Key Laboratory for Polymer and Composite Materials, Bach Khoa University; \\ nthhoa@hcmut.edu.vn,phamtrungkien@hcmut.edu.vn,hdphu@hcmut.edu.vn
}

\begin{abstract}
Polylactic acid (PLA) microfibrous composite scaffolds having hydroxy apatite (HA) particles in the fibers were prepared by electrospinning of PLA and wet chemical hydrothermal reaction HA with average diameter of $8.13 \mu \mathrm{m}$. The fibers were compressed in mould into bulk scaffolds. Microscopy characterizations confirmed integration of the crystalline HA and PLA fibers in both before and after compression. The morphology, porosity of scaffolds were examined by scanning electron microscope (SEM). The HA content were observed by SEM and determined by Thermogravimetry Analysis (TGA). Agglomeration gradually appeared and increased on the fiber surface along with the increase of HA concentration. The fiber diameter also increased with the HA concentration. Mechanical property of scaffold was examined by compressional strength test. The scaffold prepare for bone substitute implant application with suitable mechanical performance and morphology.
\end{abstract}

Keywords. PLA, HA, electrospinning, scaffold, wet chemical hydrothermal reaction.

\section{INTRODUCTION}

Frame tissue (scaffold) is the artificial structure capable of supporting the formation of cell tissue in three dimensions when cells were implanted into the frame. Framework for tissue can be used for tissue culture both in vitro and in vivo $[1,2]$. Scaffold transplants cells to create an environment similar inside the body and allows the cells develop their nutrient environment. Scaffolds HA have many functions: create supportive framework for the cells attach and grow, transport or retain cells and biochemical factors, support the diffusion of nutrients and transport the products of cells, regulate cell growth. Frame tissue requires highly porous structure, uniform pore size and suitable size to facilitate cell to cell cultivation and transportation of biomass. Biodegradation is also an important HA characteristic, a frame size will be destroyed and lost without surgery to remove. The frame material tissue and their decomposition products must be biocompatible to minimize the inflammation and the rejection of the body $[3,4]$.

Various technologies have been developed to fabricate three-dimensional (3D) porous scaffolds, example: Gas Foaming, Emulsification/Freeze-drying of which electrospinning HA has been proven to be a simple and versatile technology for producing ultrathin non-woven fibers with a diameter ranging from nanometers to microns. The electrospun nanofibers possess a lot of advantages such as an extremely high surface-to-volume ratio, a small inter-fibrous pore size with tunable porosity as well as vast possibilities for achieving desirable properties and functionalities, thus HAve been widely used in areas of filtration, composite reinforcements, optical and chemical technologies, drug delivery and tissue engineering. A variety of materials including polymers, ceramics and their composites can be electrospun into fibrous scaffolds. However, considering the requirements of biomimetic structure, good mecHAnical strength and bioactivity, synthetic degradable polyesters including polylactide (PLA) and polyglycolide (PGA) are usually used as the scaffold matrix and could be further integrated with inorganic minerals. The poly $(\mathrm{L}-$ lactide) (PLLA) and poly(D-lactide) (PDLA) require at least 24 months and 12-18 months to finish the degradation. Therefore, poly lactide is prospective for tissue engineering due to its mechanical properties, 
biodegradation products, flexibility for the clinical applications. Indeed, PLA is currently widely used as scaffold materials for bone repair with good biocompatibility, non-toxicity and non-inflammation.

In this work, we present results of research on manufacturing of PLA nanofibrous composite scaffolds containing wet chemical hydrothermal reaction HA by electrospinning method and compression molding.

\section{MATERIALS AND METHODS}

\subsection{Materials}

PLA is imported from Korean, molecular weight Mn about $106760 \mathrm{~g} / \mathrm{mol}, 99 \%$ purity, glass transition temperature from $58-60{ }^{\circ} \mathrm{C}$, melting point at $184^{\circ} \mathrm{C}$. HA is fabricated within wet chemical hydrothermal reaction in our laboratory. The used solvent is chloroform and acetone.

\subsection{Methods}

\section{Electrospun fibers processing methods}

A pre-determined amount of the HA powder was added into $14 \mathrm{ml}$ Aceton/Cloroform (3/4 volume ratio). The mixture was sonicated for 15 mins to disperse the hydroxyapatite, into which $0.3 \mathrm{~g}$ PLA was added and dissolved at $40{ }^{\circ} \mathrm{C}$ overnight. The mixture was further magnetically stirred for $15 \mathrm{mins}$, followed by ultrasonication for another 15 mins to obtain the well-mixed PLA/HA suspension with a PLA concentration of $7 \mathrm{wt} \%$. The PLA/HA nanofibrous composite scaffold was prepared by electrospinning of the mixture suspension. Briefly, the as-prepared suspension was added into a plastic syringe equipped with a needle with an inner diameter of $1.2 \mathrm{~mm}$. The syringe was then mounted onto a syringe pump, in which the needle was connected to a high voltage power supply. Under $24 \mathrm{kV}$, the fluid jet was injected out at a rate of $6.0 \mathrm{ml} / \mathrm{h}$ and the resultant nanofibers were collected on an aluminum foil which was put at $15 \mathrm{~cm}$ away from the needle. After electrospinning for $2 \mathrm{~h}$ at room temperature, the PLA/HA nanofibrous composite scaffold was obtained. Pure PLA nanofibers were also prepared as the control. The nanofibrous scaffolds were dried in ventilating cabinet for $24 \mathrm{~h}$ to evaporate the residual solvent.

\section{Morphology}

After coated with a thin gold layer, the HA and scaffolds were observed under a scanning electron microscope (SEM, National institute of Hygiene and Epidemiology (NIHE)). The diameter and pore size of the nanofibers were measured by an image analysis software (Image J) from at least 30 fibers. For Thermogravimetric analysis (TGA), measurement is used to determine the concentration of HA on-micron nanofibers. The measurement was done at University of Pedagogy Ho Chi Minh City.

\section{Compressive Strength}

Measurement is used to determine the compressive strength of the scaffolds. The measurement is done by machine Rubber Testometric Lab. B2, Ho Chi Minh City University of Technology.

\section{RESULTS AND DISCUSSION}

\section{Morphology and structure of the nanofibrous Scaffolds}

In composite materials, the surface and inner structure and distribution of the components HAve a decisive impact on the materials properties. For tissue engineering application, distribution of the HA inand-outside of the fibers will further influence cytocompatibility of the scaffolds, such as cell adhesion and proliferation. Therefore, morphology and structure of the PLA/HA electrospun scaffolds were observed under SEM, as shown in Figure 2. In this experiment, a series of PLA/HA composite nanofibers with different HA amount were fabricated. The PLA/HA electrospun scaffolds showed a randomly interconnected and highly porous structure which was composed of continuous bead-free nonwoven nanofibers. The fiber diameter increased from $4478 \pm 1692 \mathrm{~nm}$ (for the $5 \%$ HA/PLA) to $8135 \pm 2905 \mathrm{~nm}$ (for the $10 \% \mathrm{HA} / \mathrm{PLA}$ ) and further to $9238 \pm 2257 \mathrm{~nm}$ after addition of 5\%HA, respectively (Table 1). 


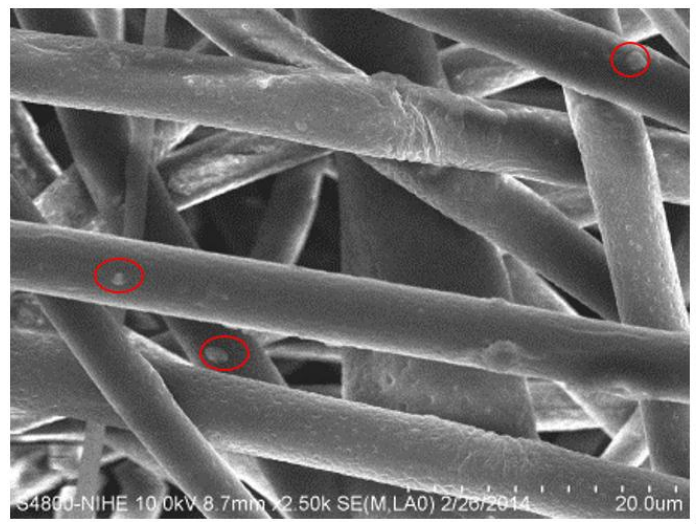

a)

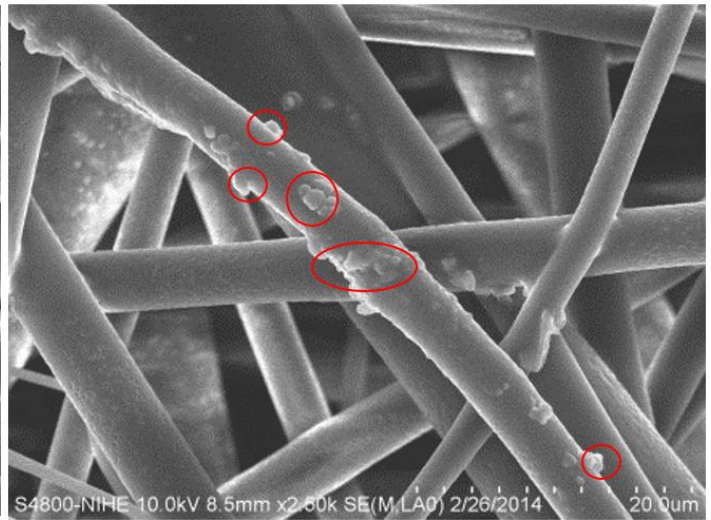

b)

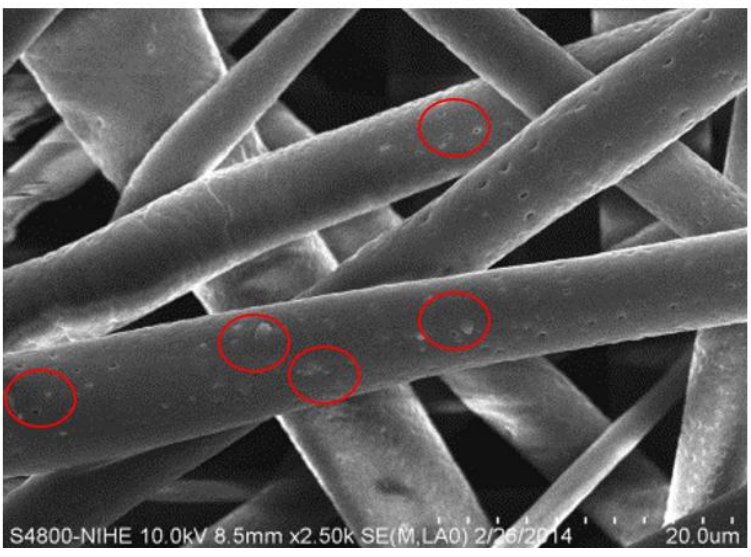

c)

Figure 2. SEM images to show surface morphology of: a) $5 \%$ HA/PLA b) $10 \%$ HA/PLA and c) $15 \%$ HA/PLA nanofibrous scaffolds.

Table 1. Diameter and pore size of nanofibrous scaffolds.

\begin{tabular}{|c|c|}
\hline Sample & Diameter(nm) \\
\hline 5\%HA/PLA & $4478 \pm 1692$ \\
\hline 10\%HA/PLA & $8135 \pm 2905$ \\
\hline 15\%HA/PLA & $9238 \pm 2257$ \\
\hline
\end{tabular}

However, the pore size of all the scaffolds remained more or less constant with an average value of about $3000 \mathrm{~nm}$ regardless of the HA addition. This is quite common for the electrospun fibrous scaffolds, in which the pores are formed by the alignment of the injected fibers and thereby can be only varied within a small range. This is consistent with a previous study, in which the pore size was not significantly varied although the diameter of polystyrene nanofibers was decreased along with the increase of voltage [22]. However, surface structure of the nanofibers varied apparently after addition of the HA. Compared with a smooth morphology of the $5 \% \mathrm{HA} /$ PLA nanofibers (Figure 2a), a rough surfaces were observed for all the composite scaffolds (Figure 2a-c). A few tiny particles were found on the fiber surfaces when 5\% HA was more added (Figure $2 \mathrm{~b}$ ). When the amount was further increased to 15\% HA, the surface of the fibers was even entirely covered by a layer of nanoparticles (Figure 2c). A similar phenomenon was also observed by Thomas et al. [23], in which surface roughness of collagen/20\% nano HA composite fibers was substantially larger than that of pure collagen fibers. Deng et al. [24] also reported the coarseness of the PLLA/HA hybrid nanofibrous scaffolds, although the average fiber diameter did not vary significantly. In this regard, the electrospun composite nanofibers of PLA and HA could better mimic the micro/nano-structure of the natural bone [16]. With increase of the HA amount, the agglomeration became serious, and more and more particles attached on the fiber surfaces (Figure $2 b-c$ ). This observation is consistent with the structure of 
the HA, revealing the successful fabrication of the bone structure biomimetic PLA/HA nanofibrous composite scaffolds.

\section{TGA results of samples electrospinning fibers}

According to the TGA schema of $100 \%$ PLA fibers and $10 \%$ HA/PLA sample corresponding to Figure 3a: $100 \%$ PLA sample started to decompose at $232.11^{\circ} \mathrm{C}$ and completely decomposed at $393.04{ }^{\circ} \mathrm{C}$ in 38.9 minutes. Also, $10 \% \mathrm{HA} / \mathrm{PLA}$ sample started to decompose at $230^{\circ} \mathrm{C}$ and decomposed completely at $340{ }^{\circ} \mathrm{C}$. Decomposed PLA amount was $4.579 \mathrm{mg}$, representing $89.78 \%$.

From the comparison of two samples above, we can know is that HA was successfully dispersed in the PLA, with HA percentage have been $100 \%-89.78 \%=10.22 \%$. This content is consistent with the initial amount of HA.

a)

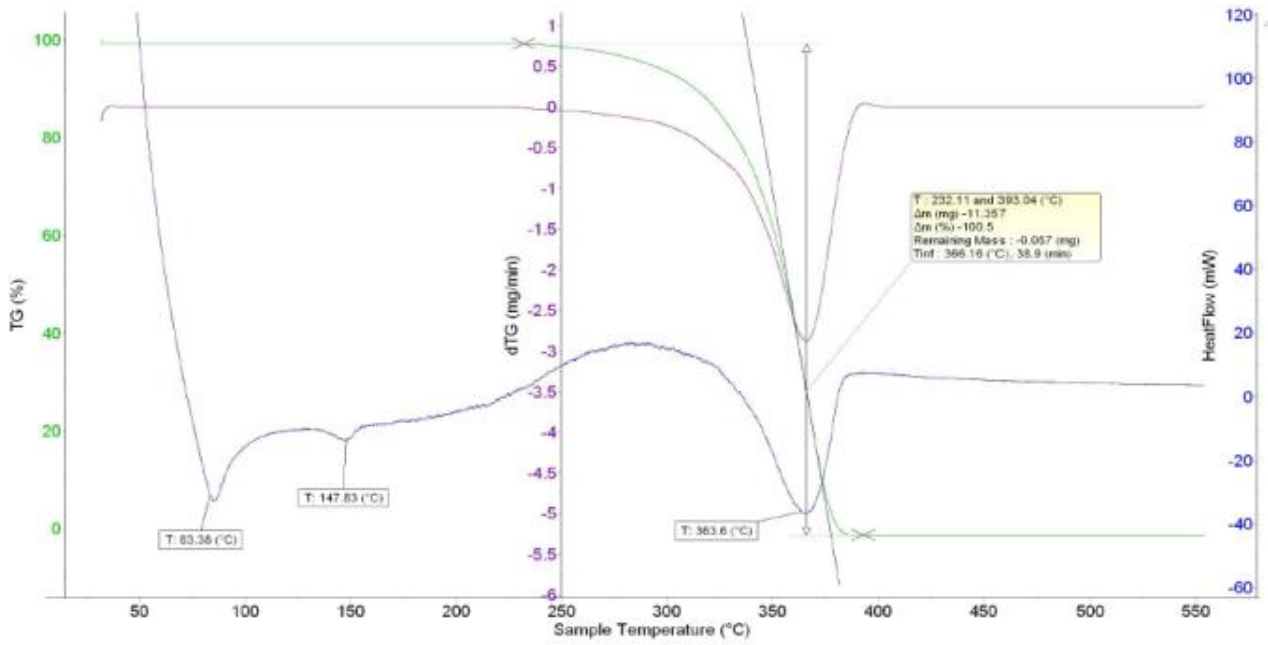

b)

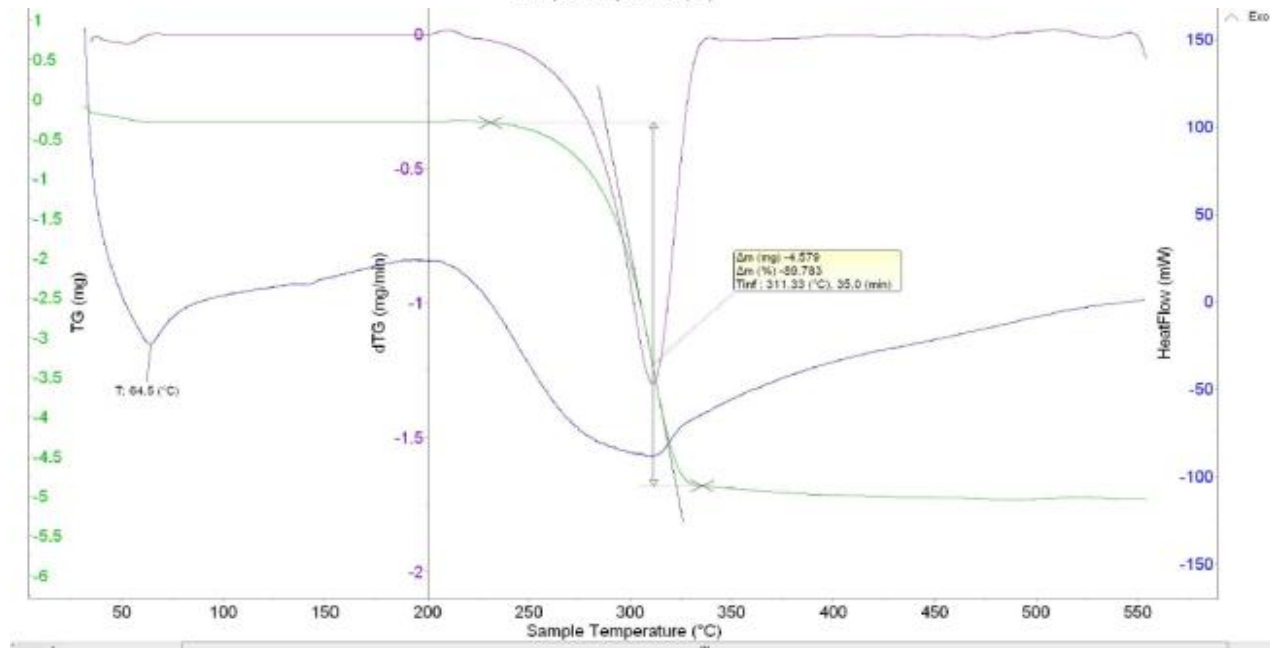

Figure 3. a) TGA schema of $100 \%$ PLA fibers, b) TGA schema of $10 \%$ HA/ PLA fibers.

\section{Morphology and structure of the nanofibrous bulk Scaffolds}

As can be seen in Figure 4, fiber structure remained intact because the scaffold were curled when put into the mold to press in order not to cause tear, fiber deformation. In addition, by correct calculating weight of material put into the mold, Scaffold layer will be pressed closer, more closely together and not break the fiber structure.

The amount of material ensured porosity and ensure mecHAnical property of the bulk scaffold. HA particles are still clinging on PLA fibers, not be separated from the scaffold blocks. 


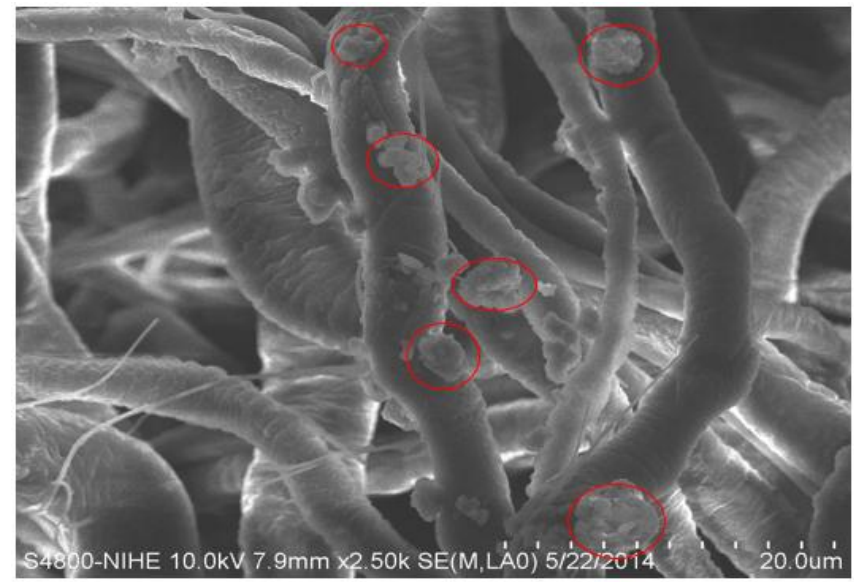

Figure 4. SEM images to show surface morpholog of bulk scaffolds.

\section{Compression strength of scaffold}

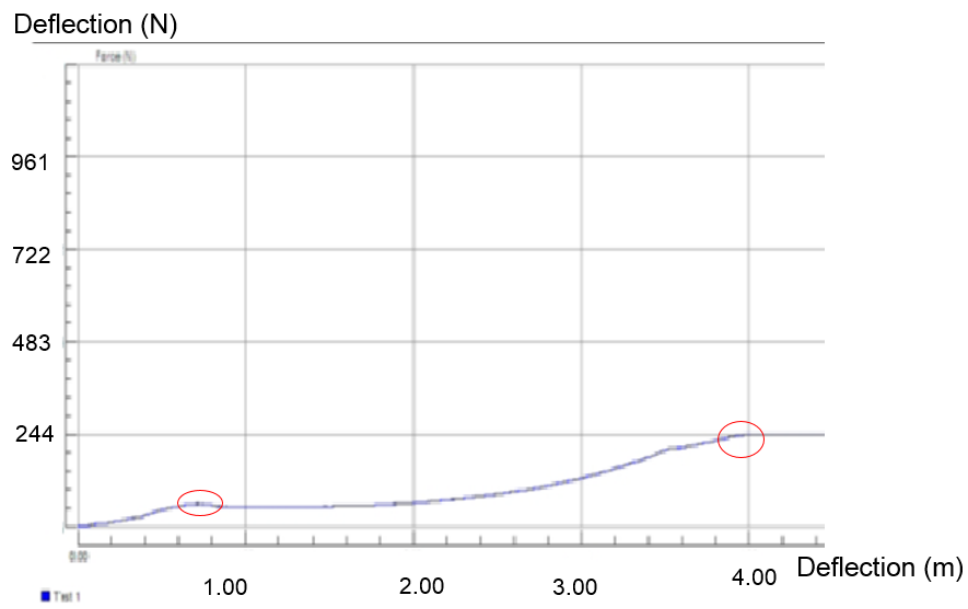

Figure 5. Compression strength of scaffold.

As shown in Figure 5, the deformation started at $70 \mathrm{~N}$ at the weak link contact line between HA particles and PLA. Stress-strain point was $4.49 \mathrm{~N} / \mathrm{mm} 2$. After deformation, the internal molecular rearrange, PLA covered HA particles make the strength gradually increase to $244 \mathrm{~N}$, samples were destroyed completely. The stress destruction scaffold is calculated 15,65 N/mm2.

\section{CONCLUSIONS}

Biodegradable PLA nanofibrous composite scaffolds incorporated with bone matrix-mimic hydroxyapatite particles were successfully prepared by electrospinning of PLA solution HA. At a lower concentration, HA was uniformly dispersed on the fiber surfaces. Along with increase of the HA concentration, larger agglomerates gradually covered on the fibers. Biomineralization in the PLA/HA nanofibrous scaffolds was pronouncedly enhanced HA in the control PLA scaffolds. Integration of the HA with the PLA nanofibers is a meaningful way to obtain nanofibrous scaffolds with better physical and biological performance, which are more attractive for bone regeneration too.

\section{ACKNOWLEDGMENT}

This work was financially supported by Ho Chi Minh City University of Technology and Vietnam National University - Ho Chi Minh through the Science and Technology Funds granted for T911-CNVL2016-02 projects. 


\section{REFERENCES}

[1] Scott A. G., Jefferey O. H., An introduction to Biomaterial, CRC Press, 2006.

[2] Lijie Zhang, Thomas J. Webster, Review-Nanotechnology and nanomaterials: Promises for improved tissue regeneration, Nano Today, 2009.

[3] Kay C. Dee, David A. Puleo, Rena Bizios, An Introduction to Tissue - Biomaterial Interactions, John Wiley \& Sons, 2000.

[4] Webster T. J., Ahn E. S., Nanostructured biomaterials for tissue engineering bone, Adv Biochem Eng Biotechnol, 2007.

[5] Schmidt P. C. and Herzog R., Calcium phosphate in pharmaceutical tableting, Pharmacy World and Science, vol. 15, pp. 105-115, 1993.

[6] Huang Z. M., ZHAng Y. Z., and Kotaki M., A review on polymer nanofibers by electrospinning and their applications in nanocomposites, Compos Sci Technol, vol. 63, pp. 2223-2253, 2003.

[7] Lao L., Wang Y., Zhu Y., Zhang Y., Gao C., Poly(lactide-co-glycolide)/hydroxyapatite nanofibrous scaffold fabricated by electrospinning for bone tissue engineering, J. Mater Sci Mater Med. 22, pp. 1873-1884, 2011.

[8] Furcola N. C., ASTM F-1088-04a - Standard specification for composition of hydroxyapatite for surgical implant (2005).

[9] Neih T. G., Synthesis and Charaterrization of porous Hydroxyapatite and Hydroxyapatite coating, Lawren Livermore Lab, USA 4, pp. 138, 2000.

[10] Sill T. J., von Recum H. A., Electrospinning: applications in drug delivery and tissue engineering, Biomaterials, vol. 29, no. 13, pp. 1989-2006, 2008.

[11]Liu G., Ding J., Qiao L., Guo A., Dymov B. P., Gleeson J. T., Hashimoto T. and Saijo K., Polystyrene-blockpoly(2-cinnamoylethyl methacrylate) nanofibers: Preparation, characterization, and liquid crystalline properties, Chem-A European J , vol. 5, pp. 2740-2749, 1999.

[12]Feng L., Li S., Li H., Zhai J., Song Y., Jiang L. and Zhu D., Super-Hydrophobic Surface of Aligned Polyacrylonitrile Nanofibers, Angew Chem Int Ed 41, pp. 1221, 2002.

[13] Deitzel J. M., Kleinmeyer J., Hirvonen J. K., Beck T. N. C., Controlled deposition of electrospun poly (ethylene oxide) fibers, Polymer, vol. 42, pp. 8163-8170, 2001.

[14] Wen X., Tresco P. A., Fabrication and characterization of permeable degradable poly(DL-lactide-co-glycolide) (PLGA) hollow fiber phase inversion membranes for use as nerve tract guidance channels, Biomaterials, vol. 27 , no. 20, pp. 3800-3809, 2006.

[15] Schmidt C. E., Leach J. B., Neural tissue engineering: strategies for repair and regeneration, Annu Rev Biomed Eng 5, pp. 293-247, 2003.

[16] Murugan R., Ramakrishna S., Development of nanocomposites for bone grafting, Compos Sci Technol, vol. 65, no. 15, pp. 2385-2406, 2003.

[17] Jose M. V., Thomas V., Johnson K. T., Dean D. R., Nyalro E., Aligned PLGA/HA nanofibrous nanocomposite scaffolds for bone tissue engineering, Acta Biomaterialia, Vol. 5, Iss. 1, pp. 305-315, 2009.

[18] Sopyan I., Mel M., Ramesh S., KHAlid K. A., Porous hydroxyapatite for artificial bone applications, Sci Technol Adv Mater 8, pp. 116-123, 2007. 
[19] Huang Z. M., ZHAng Y. Z., Kotaki M., Ramakrishna S., A review on polymer nanofibers by electrospinning and their applications in nanocomposites, Compos Sci Technol., vol. 63, no. 15, pp. 2223-2253, 2003.

[20] Martinez E., Engel E., Planell J. A., Samitier J., Effects of artificial micro- and nano-structured surfaces on cell behaviour, Ann Anat, vol. 191, no. 1, pp. 126-135, 2009.

[21]Deng X. L., Sui G., Zhao M. L., Chen G. Q., Yang X. P., Poly(L-lacticacid) /hydroxyapatite hybrid nanofibrous scaffolds prepared by electrospinning, J Biomater Sci Polym Ed., vol. 18, no. 1, pp. 117-130, 2007.

[22] Megelski S., Stephens J. S., CHAse D. B., Rabolt J. F., Micro- and nanostructured surface morphology on electrospun polymer fibers, Macromolecules, vol. 35, pp. 8456-8466, 2002.

[23] Thomas V., Dean D. R., Jose M. V., Mathew B., Chowdhury S., Vohra Y. K., Nanostructured biocomposite scaffolds based on collagen coelectrospun with nanohydroxyapatite, Biomacromolecules, vol. 8, pp. 631-637, 2007.

\section{VẬT LIỆU SCAFFOLD SINH HỌC TÙ̉ SỌ̆I MICRO-NANO ELECTROSPUN POLYLACTIC ACID và HYDDRXY APATITE HẤP THỦY NHIẸT}

Tóm tắt. Composite khung giàn giáo từ vi sợi poly(lacticacid) (PLA) và vi hạt hydroxy apatite (HA) hấp thủy nhiệt đã được điều chể bằng phương pháp quay vi sợi điện trường giữa PLA và HA với đường kính trung bình HA là $8,13 \mu \mathrm{m}$. Các vi sợi được nén trong khuôn thành khối đặc cấu trúc giàn giáo. Các đặc trưng hình thái mẫu tạo thành quan sát với kính hiển vi điện tử quét (SEM) xác nhận sự kết hợp của tinh thể HA và vi sợi PLA trước và sau khi ép khối như hình thái học, độ xốp. HA được quan sát qua ảnh SEM và được xác định hàm lượng bằng phân tích nhiệt khối lượng (TGA). Sự kết tụ dần xuất hiện và tăng cường trên bề mặt dọc sợi khi tăng hàm lượng HA trong hỗn hợp. Đường kính sợi cũng tăng với nồng độ HA. Cơ tính của sản phẩm vật liệu được kiểm tra bằng phép thử nén. Khung giàn giáo sinh học được chuẩn bị cho ứng dụng cấy ghép xương thay thế với đặc tính cơ học và hình thái học tương thích.

Từ khóa. PLA, HA, electrospinning, scaffold, hấp thủy nhiệt. 